\title{
The Employment Status of Nigerian Workers in the Gig Economy: Using Uber as a Case Study
}

\author{
N. Ejims Enwukwe*
}

\begin{abstract}
Owing to strides in technology like mobile applications and online platforms, thousands of Nigerian workers now earn a decent income through 'gig" work, which affords them the flexibility to set their own hours and choose which jobs to take or not to take. This growth, which has become dominant in the last five to seven years, has however sparked concerned over the lack of rights and status given to these workers in such industries. In May 2017, Uber cut fares by 40\%, thereby triggering drivers strike in Lagos Nigeria commercial city. In Abuja, Nigeria capital city, low fares in addition to the high commission rates have been an ongoing tussle between Uber and their drivers. ${ }^{1}$ According to one aggrieved driver, 'They don't even consult with us. What is the essence of a partnership if decisions are one way? ${ }^{2}$ More recently the Lagos state Government had a round table discussion with these tech companies and thereafter introduced stringent regulatory measures for ride hailing companies such as Uber, Taxify (now Bolt) to mention a few. However, this did not sit well with the drivers of these platforms who have been absent from the negotiations. They expressed dissatisfaction at not being invited to the round table discussion, citing the fact that these ride-hailing companies never saw them as employees but merely as contractors. ${ }^{3}$ This article seeks to examine the employment status of these gig workers in Nigeria. It suggests that introducing a third force, i.e a new category of workers called "the independent employee" that would fit into the modern day economy may provide the much-needed solution to this lacuna.
\end{abstract}

Keywords: Employment, Gig workers, Nigeria, Independent Employee

DOI: $10.7176 / \mathrm{JLPG} / 107-08$

Publication date:March $31^{\text {st }} 2021$

\section{INTRODUCTION}

Across Nigeria, the globally accepted uber model has been gaining momentum in recent years. The uber model is now increasingly visible in many other Nigerian states. Thus it has become imperative to examine the dazzling success story of the Uber model, which is heavily inspired by the gig-based business model. ${ }^{4}$

More and more companies in the gig economy resort to utilizing independent contractors rather than the traditional employees for work with a model that typically still retains control over work that would have ordinarily been done by employees. They have done this so as to reduce cost and minimize employment related liability associated with a worker with an employee status. ${ }^{5}$ Simply put, the law protects employees in various ways that it does not protect independent contractors. ${ }^{6}$ Thus, claims of worker misclassification have plagued the Gig Economy because they call into question the very nature of the services provided by, and to, its participants. ${ }^{7}$ To be clear, worker misclassification problems are by no means exclusive to the Gig Economy ${ }^{8}$

One underlying characteristics of these new gig economy platforms is that they operate in interstitial areas of the law because they present new and unique challenges that were not foreseen and were also not accommodated in our existing laws and regulations. ${ }^{9}$ Not surprising that a considerable number of lawsuits has distracted their success in light of the legal ambiguities these new companies present, some of which may have the capacity to permanently derail or destroy their burgeoning business models. ${ }^{10}$ On one hand, some authors have insisted that the employment lawsuits against these companies are a huge threat to the success of the gig

\footnotetext{
* LL.B, BL, LLM (Corporate \& Financial Law, Kingston University London), Lecturer, Department of Business Law, Faculty of Law, Rivers State University, Email: ndamenem.enwukwe@ust.edu.ng

${ }^{1}$ Yomi Kazeem, 'Uber has a new problem in Nigeria - driver stikes in Abuja.' Quartz Africa. 2016 > https:/qz.com/africa/823361/uberdrivers-in-abuja-are-going-on-strike-to-protest-low-fares/ > accessed $1^{\text {st }}$ June 2020

2 National Union of Professional E-Hailing Driver Partners (NUPEDP). Facebook page 2018 > https://www.facebook.com/nupedp.nupedp.1 > accessed 6th June 2020

3 Emmanuel Paul, 'What you need to know as Lagos plans to enforce regulation on uber, Bolt(Taxify) others' https://techpoint.africa/2020/03/03/lagos-regulation-ride-hailing/ > accessed 2 April 2020

${ }^{4}$ Orly Lobel, 'The Gig Economy \& the Future of Employment and Labor Law' (2017) 51 USF L Rev 51

${ }^{5}$ Ben Z Steinberger, 'Redefining Employee in the Gig Economy: Shielding Workers from the Uber Model' (2018) 23 Fordham J Corp \& Fin L 577

${ }^{6}$ see the case of, O'Connor v. Uber Techs., Inc., 82 F. Supp. 3d 1133, 1137-38 (N.D. Cal. 2015).

${ }^{7}$ Michael L Nadler, 'Independent Employees: A New Category of Workers for the Gig Economy' (2018) 19 NC JL \& Tech 443

${ }^{8}$ Orly Lobel, 'The Law of the Platform', (2016) 101 MINN. L. REv. 87, 135-36

${ }^{9}$ Roberta A. Kaplan \& Michael L. Nadler, 'Airbnb: A Case Study in Occupancy Regulation and Taxation' [2015]. 82 U. CI. L. REV. DIALOGUE 103, 104

10 Sarah Kessler, The Gig Economy Won't Last Because It's Being Sued to Death, [Feb. 17, 2015], https://www.fastcompany.com/3042248/the-gig-economy-wont-last-because-its-being-sued-to-death > accessed 4th April 2020
} 
economy but also argue on the other hand that if the gig economy companies cannot adequately classify its workers, then 'We all lose the gig economy'. ${ }^{1}$ Although many have suggested that a new category of worker would be beneficial to labour law practice, they have however failed to explain what such a category would look like in actual practice. ${ }^{2}$ Others on the other side of the divide have dismissed the notion of creating a new third force. According to them, what need to be done is to reject the so-called classification doctrine, expand certain employment protections to all workers, and to dissociate certain social protections from workers. ${ }^{3}$ The courts on their part have not only struggled to characterize many of the non traditional working arrangements utilized by the gig-economy, they have also failed to ratify the fundamental flaws with their business models. ${ }^{4}$ More worrisome, that different courts have analyzed Uber's employment framework under the traditional test, yet reached opposite conclusions regarding driver's employment status even when predominantly considering the same facts and circumstances. ${ }^{5}$

The writer suggests that introducing a third force, i.e a new category of workers called "the independent employee" that would fit into the modern day economy may provide the much needed solution to this lacuna thus putting an end to the many flaws inherent in our binary classification of workers as either employees or independent contractors. ${ }^{6}$ This article would be the first in Nigeria to engage with the existing workers misclassification to outline a new category, "the independent employee" which would provide both the companies and workers the much-needed advantage over the status quo.

\subsection{UNDERSTANDING THE GIG ECONOMY THROUGH THE UBER BUSINESS MODEL}

The "gig-economy" is one of several terms used to describe the advent of companies that do not offer any direct services of their own, but instead act as intermediaries between workers and customers. ${ }^{7}$ The rise in gig economy has been accompanied by impressive PR campaign to promote its employment practices as "the future" of work. ${ }^{8}$ In fact, it has also been claimed that the gig economy promotes entrepreneurship, allowing business owners to balance working with starting their own business. ${ }^{9}$ Thus the model that Uber has engineered and developed is at the core of the gig economy.

Uber is a digital business, which affords customers the platform to request for drivers via a smartphone app. So whenever a request is made and a nearby driver accepts the request, the app then provides the information about the said driver, which includes the driver's name, vehicle type, and number plate to the potential rider. Upon arriving at the location, the app calculates the fare and charges it to the customer's Uber account. ${ }^{10}$

Surprisingly, Uber has often maintained [argued] that they do not employ drivers neither do they own the vehicles. They insist that they are not a transportation company but merely provides a platform for persons who own vehicles to utilize their skills and personal assets and connect with other people looking to pay for those skilled assets. ${ }^{11}$ Now, a close look at the Uber business model shows there are some element that suggest independent contractor status for the drivers and this is because these drivers provide the instrumentalities for their work i.e. the cars, are paid by the number of pick up jobs they are able to carry out daily, thus they control their work hours, their geographical area for pickups as well as whether or not to accept a passengers request for a ride. On the other hand, there are also some elements that posit employee status for the drivers. It is a fact that Uber imposes certain requirements and some degree of control on its drivers. Thus Uber is deeply involved in marketing its transportation services; qualifying and selecting drivers (drivers must pass a valid background check from the police), setting pay rate and the method of pay ${ }^{12}$, disciplining (or terminating) those who fail to meet standards ${ }^{13}$ and regulating as well as monitoring their performance ${ }^{14}$ In addition, these drivers must have a four-door vehicle and must be interviewed before they can be brought on board the platform. All these control

\footnotetext{
${ }^{1}$ ibid; ibid(n7)

${ }^{2}$ Caroline O'Donovan, What a New Class of Worker Could Mean for the Future of Labor, BUZZFEED (June 18, 2015, 5:01 PM), https://www.buzzfeednews.com/article/carolineodonovan/meet-the-new-worker-same-as-the-old-worker > accessed 12 April 2020 ; Michael L Nadler, 'Independent Employees: A New Category of Workers for the Gig Economy' (2018) 19 NC JL \& Tech 443

${ }^{3}$ ibid (n4)

${ }^{4}$ ibid (n7)

${ }^{5}$ see the case of Aslam, Farrarv Uber ET Case No 2202550/15; Ben Z Steinberger, 'Redefining Employee in the Gig Economy: Shielding

Workers from the Uber Model' (2018) 23 Fordham J Corp \& Fin L 577

${ }^{6}$ ibid (n7)

${ }^{7}$ Andrew G Malik, 'Worker Classification and the Gig-Economy' (2017) 69 Rutgers UL Rev 1729

${ }^{8}$ Hilary Hogan, 'Rewinding the Clock: Workers' Rights in the Gig Economy' (2020) 9 King's Inns Student L Rev 114

${ }^{9}$ Anirudh Mandagere, 'Examining Worker Status in the Gig Economy' (2017) 4 J Int'l \& Comp L 389

${ }^{10}$ How does Uber Work? > https://help.uber.com/riders/article/how-does-uber-work?nodeId=738d1ff7-5fe0-4383-b34c-4a2480efd71e > accessed $28^{\text {th }}$ may 2020

${ }^{11}$ Salovitz v. Uber Tech., Inc., 2014 WL 5318031, at 1 (W.D. Tex. Oct.16,2014)

${ }^{12}$ In Nigeria, payment are made either by cash or card although cash payments are not allowed in other countries like the United Kingdom.

${ }^{13}$ Uber removes drivers who fall below a 4.6 rating from the app

${ }^{14}$ Ben Z Steinberger, 'Redefining Employee in the Gig Economy: Shielding Workers from the Uber Model' (2018) 23 Fordham J Corp \& Fin L 577
} 
Uber exercises on their drivers raises the very issue of misclassification and leaves so many questions yet to be answered.

For context, If Uber had merely sold its app to self-employed taxi drivers and left it to drivers to negotiate fares directly with passengers, the implication is that such drivers would not be considered "workers". ${ }^{1}$

3.0 WHY DOES WORKERS CLASSIFICATION EVEN MATTER? What do we even care?

Whether or not a worker is classified as an independent contractor or an employee has implications in areas of taxation, tort liability etc. Thus there are far-reaching consequences, which ordinarily reflects an important distinction in the relationship between these workers and their companies: the very basic distinction between employee and independent contractor is control. ${ }^{2}$

Misclassified workers are often denied statutory benefits and protections, which an employee ordinarily enjoys such as minimum wage, health insurance, unemployment insurance benefits for those laid off, safe workplace, indemnity, workers compensation for those who may have sustained any injury in the cause of duty etc. Employees also enjoy the right to unionize under the Act. $^{3}$

Employee misclassification generates substantial losses to the Federal and State Government in the form of lower tax revenues as well as to state unemployment insurance and workers' compensation funds. ${ }^{4}$ As Andrew Malik rightly asked, are gig-economy companies really just another attempt to avoid the costs and encumbrances associated with employees? Or are these companies a response to market trends to which the law should recognize and adapt to ${ }^{5}$ It would however seem as though these companies are not trying to circumvent the law but rather simply do not fit into the already existing legal framework that was developed in different time and dichotomy. On the other hand, many have insisted that these companies are really just a new take on an old trick: slashing labour costs by misclassifying employees as independent contractors. ${ }^{6}$

If anything is to go by, the issues of workers classification in the gig economy affords us with different scenarios for discussion. The first is that individuals working for these companies are actually employees and should be entitled as well as enjoy the rights and benefits accorded to employee status in Nigeria. This position have been canvassed by many scholars who insist that there are no problems to be resolved and that workers are adequately classified as employees under the existing law. ${ }^{7}$ Although the courts in other jurisdiction has ruled that the traditional test for workers classification is not adequately captured in the gig economy, ${ }^{8}$ the implication however is that on one hand Uber and its likes would have to provide their workers with the full gamut of employee rights and protections if these assertions are anything to go by while they will ordinarily expect the workers to behave like employees on the other hand. ${ }^{9}$ Again this could result in the failure of many of these companies and part time employee status may also make employee worse-off. Forcing companies to provide these benefits would likely result in companies restructuring how they conduct their business to avoid going under because many of these gig companies actually depend on workers who value the flexibility of being independent contractors. ${ }^{10}$ Another downside is that these companies may likely increase their cost structure, which may result to reduction to customer welfare as these costs will be passed on to "we the platform users"

The second scenario is that persons working for these companies are adequately classified as independent contractors or partners. If this scenario is anything to go by, what it means is that these workers actually enjoy total independence and are generally in control of the work they do without any interference from these firms. They are able to set their own hours and may work as much or as little as they desire. ${ }^{11}$ Fact-check indicates that some workers may actually prefer the independent status for tax related reasons. In fact, a survey conducted in the US indicates that independent workers tend to have a higher degree of satisfaction with their jobs than standard employees do. ${ }^{12}$

\footnotetext{
1 ibid (n19)

2 ibid (n17)

${ }^{3}$ sec 1(1) Trade Union Act; Anigboro v. Sea Trucks (Nigeria) Ltd [1995] 6 NWLR (Pt 399); sec. 9(6) of the Labour Act also guarantees the right of the workers not to be dismissed on account of trade union membership

4 Misclassification of employees as independent contractors US Dep't lab, Wage \& hour division > https://www.dol.gov/agencies/whd/flsa/misclassification $>$ accessed $9^{\text {th }}$ June 2020

5 ibid (n17)

${ }^{6}$ ibid

7 Jennifer Pinsof, 'A New Take on an Old Problem: Employee Misclassification in the Modern Gig Economy' (2016) 22 MICH. TELECOMM. \& TECH. L. REV. 355; Brishen Rogers, 'Employment Rights in the Platform Economy: Getting Back to Basics' (2016) 10 HARV. L. \& POL'YREV. 479, 513

${ }^{8}$ The US Federal Judiciary in the case of Lawson v. Grubhub, Inc., No. 15 Civ. 5128 (N.D. Cal.), Cotter v. Lyft, Inc., No. 13 Civ. 4065 (N.D. Cal.), and O'Connor v. Uber Techs. Inc., No. 13 Civ. 3826 (N.D. Cal.).

9 Misclassification of employees as independent contractors US Dep't lab, Wage \& hour division > https://www.dol.gov/agencies/whd/flsa/misclassification $>$ accessed $9^{\text {th }}$ June 2020

11 Tx Zhuo, Are Sharing-Economy Workers Contractors or Employees (Entrepreneur 28 ${ }^{\text {th }}$ August 2015), > https://www.entrepreneur.com/article/249439> accessed 11th June 2020

12 Us Govt Accountability Office, 'Contingent Workforce: Size, Characteristics, Earnings, And Benefits' (April 20, 2015)
} 
The third scenario presented thus is that neither the independent status nor the traditional employee status fully and satisfactorily captures the relations between these companies and gig workers. Assuming this position is correct, the implication however is that a third category could remedy the shortcomings of the existing employee/independent contractor framework that these gig firms ride on. ${ }^{1}$ This possibility shall be explored further hence lets call it the "Independent employee" status for Nigerian workers.

\subsection{THE INDEPENDENT EMPLOYEE STATUS}

There is a good reason to believe that the vast majority of gig economy workers are not dependent on the platform they work for, hence why the writer has chosen to aptly refer to them as "independent employee". ${ }^{2}$ Indeed, most of the Uber drivers have other sources of income with majority of the drivers describing their earnings from Uber as "a supplement to their income but not a significant source. ${ }^{3}$ So, suggesting or even arguing that these workers are dependent calls into question the most important attribute and valued feature of Gig Economy work i.e. the flexibility and autonomy that such work affords. The hallmark of the Gig Economy is that workers have significant although not complete control of when and how they perform the services they render, thus the amount of control exercised by the putative employer is an appropriate test for determining whether or not a gig economy worker is truly an independent employee rather than a traditional employee or an independent contractor. ${ }^{4}$

If the independent employee classification is anything to go by, the first question it must answer is on the issue of predictability. The traditional test used in distinguishing an employee from contractor has failed to follow the laid down legal principle thus the issue of uncertainty keeps resurfacing. ${ }^{5}$ Indeed, All workers should be entitled to know their status as of right. Why wait for parties to institute legal proceedings in order to determine their employment status? The whole idea of making laws should ordinarily be to eliminate the risk of uncertainty and help people save costs rather than rely on approaches for which no one can know where he or she stands until litigation has been concluded. On one hand, businesses struggle because they face uncertain costs, on the other hand, workers do not know their status, what benefits they are entitled to and will ultimately receive thus both recognize that the only way to resolve these issues is through expensive, protracted, and entirely unpredictable litigation. ${ }^{6}$ Unfortunately, each set of fact is peculiar to that particular case so judicial precedence provides little or no guidance as to how the judgment would swing or be decided on its merits under the myriad multifactor test that courts apply.

Lets even for a second examine different approaches to determining employment status in the gig economy. The first would be that companies would be able to exactly determine what their brand should signify, the option to choose between exercising significant control in order to supply consumers with a more uniform product or service provided by employees. The second approach is that companies would be ready and willing to relinquish all control over how the product or service is delivered by independent contractors. The final approach would have companies seeking a middle ground through the use of independent employees. To the writer's mind, this approach summarily captures the uber model as it is presently structured today.

Uber is distinct from the typical employer because it does not ensure a driver for all the end users i.e. the passengers at all times and locations and does not also guarantee a user for all drivers. In fact, what it does is simply to provide a slightly regulated platform through which available drivers and passengers can find one another. Thus because it does not need to coordinate different functions and does not endeavor to provide a uniform service each time a user logs on to the platform, it has no need to control workers in the same manner as traditional employers. ${ }^{7}$

Accordingly, there should be a rebuttable presumption that Nigerian workers are adequately classified as independent employee thus companies and their workers should enter into an agreement that expressly states that such a classification exist and applies to the contract. The defining factor here is the power vested on these workers to choose and decide whether or not they want to work as an independent employee from the very beginning of the contract. This option would automatically put an end to the multiplicity of court actions brought against these gig companies that has almost derailed the gig economy. The argument would be that if a person voluntarily chooses to be an independent employee from the on go, such a person cannot turn around to complain or demand full employment status benefits.

https://www.gao.gov/assets/670/669766.pdf

1 ibid (n17)

${ }^{2}$ Jonathan Hall \& Alan Krueger, An Analysis of the Labor Market for Uber's Driver-Partners in the United States (November 2016). NBER

Working Paper No. w22843, Available at SSRN: https://ssrn.com/abstract=2873316

3 ibid (n7)

${ }^{4}$ Keith Cunningham-Parameter, From Amazon to Uber: Defining Employment in the Modern Economy, 96 B.U.L. REV. 1673, 1684 (2016)

${ }^{5}$ In discussing the difficulty of distinguishing between employees and independent contractors, Judge Easterbrook noted the traditional tests failure to adhere to a bedrock legal principle in Secretary of Labor v. Lauritzen, 835 F.2d 1529, 1539 (7th Cir. 1987)

${ }^{6}$ ibid (n7)

7 ibid (n7) 
The second question this classification must answer is on the issue of the legal protections each worker under this category should ordinarily enjoy. To be fair, the civil rights protections that traditional employee enjoy should be extended to also cover independent employee. Thus a basic set of benefits and labor standards must be universal across all employers and all forms of employment" that would "put all employees and employers alike on an equal footing."

For instance employers should be prohibited from discriminating against independent employees on the basis of personal traits such as sex, state of origin, religion, age, or disabilities just as they prohibited from discriminating against employees based on the characteristics mentioned above.

There is no justice or social benefit achieved by allowing employer discrimination on any of the category of workers whether it is independent contractor or independent employee on the basis mentioned above. And so, the National assembly must now rise up to the challenge of extending certain protections to all categories of workers rather than withholding these protections from non-traditional employee. The Nigerian labour Act \& the Trade Union Act must be amended to allow independent employee unionize as well as collectively bargain in order to achieve a far reaching agreement for these categories of workers. More so, because gig economy companies set the prices at which workers services are offered to the end users through their platform, it is only just to allow service providers i.e. the drivers to collectively bargain with these platform companies regarding the terms and conditions under which they offer their services on those very platform.

The next question, which must also be answered if this independent employee status was to see the light of day, is the benefits afforded to these categories of workers. Uber and other big companies in the gig economy should be encouraged and incentivize to provide independent employees with benefits gotten from the economies of scale that accrue to them as a result of the services that these workers provide for them. This however would raise questions like, are small companies operating in the gig economy allowed to ignore these benefits for their workers? What is the metric for measuring whether or not a company has attained the "big company status"? Thus whether a company has attained the "big company status" may be measured by different metrics such as revenue, profits, valuation or number of workers which the company currently employs. For small companies, these benefits should be competitive amongst their ranks because big companies can provide these benefits more efficiently than small companies and so independent employee would benefits significantly from such an arrangement.

Additionally, benefits may also cover for financial and tax services such as giving car loans that would eventually be charged back on the earnings of the independent employee, assisting them in getting better terms for automobile insurance as well as procurement of the relevant permit papers to enable these workers efficiently provide their services. For example Uber drivers are prohibited from picking up passengers from anywhere around the Lagos State Airports thus Uber should be able to liaise with the relevant authorities to enable these drivers operate in all parts of Lagos rather than limiting them to certain areas.

The decision to provide these benefits should be left in the hands of Uber or other gig companies, their regulators and their workers (possibly through a trade union representation) based on their particular business model rather than giving it a statutory footing. Letting gig economy companies make the decision themselves to provide these benefits based on their business model would be a test for determining whether or not a worker is an independent employee as opposed to the traditional test for determining employment status.

The fourth question it must answer is its workability under the independent employee status. First lets examine the number of time, hours each worker under this category should ordinarily put in either on a daily or weekly basis. While some have argued that it is difficult in tracing the time, work and hours spent across platforms hence difficult in determining an hourly wage. ${ }^{2}$ Nadler insists that there is no way to conclusively measure when or for how many hours a gig economy worker is actually working and more importantly how many hours they are working for a particular company thus independent employee should not be entitled to minimum wage or overtime wages. ${ }^{3}$ However this argument shows a lack of depth understanding about the technology currently in use by gig companies. Contrary to Nadler argument, there is no lack of data or difficulty in tracing hours. Nadler insists that most drivers' work for both Uber and other competitors using both platforms to run simultaneous searches for passenger making it difficult to answer question of how much time was spent working. To the writers mind, the answer to this argument is staring right at us, if an Uber driver accepts a ride and starts a journey, it is common sense that your time starts counting the minute you accept a ride and when the said ride ends. At the end of the day the time spent is calculated based on how many rides was accepted, started and concluded.

As a matter of fact, most ridesharing apps like Uber uses real time GPS tracking and updated ratings from customers but those are just the features that we the users see. Both the drivers and end users generate additional

\footnotetext{
Nick Hanauer \& David Rolf, Shared Security, Shared Growth, 37 DEMOCRACY J. (Summer 2015), https://democracyjournal.org/magazine/37/shared-security-shared-growth/ accessed $19^{\text {th }}$ December 2020

${ }^{2}$ Miriam A Cherry and Antonio Aloisi, 'Dependent Contractors in the Gig Economy: A Comparative Approach' (2017) 66 Am U L Rev 635 ${ }^{3}$ supra
} 
data that Uber collect and analyze at the end of the day, much of which is usually for the purpose of improving future rides and performance. In fact, many gig company can actually measure precisely how much time and effort a driver spends on a ride down to even time spent waiting in traffic. Truth be told, we shouldn't concern ourselves with Nadler's argument of difficulty in calculating time spent rather our concern should be the constant and pervasive surveillance through GPS, phone and app data. ${ }^{1}$ Indeed our privacy has been invaded. The argument of exempting gig workers from minimum wage requirements seems poorly thought out and shouldn't be allowed to fly. ${ }^{2}$ Exempting certain work from minimum wage would only worsen the problem of exploitation of workers in the gig economy.

\subsection{NIGERIA: THE EXISTING STATUTORY FRAMEWORK}

In Nigeria, most of the gig workers are not under any alternative form of employment. They do gig work on a full time and part time basis depending on individual choice. Although vast majority of Uber workers prefer to have control of their time in order to balance work and family life. A review of the exiting labour laws in Nigeria reveals the vulnerability of gig workers whose existence are neither contemplated nor regulated by any law. ${ }^{3}$ The inability to adequately classify gig workers in Nigeria are hugely influenced by the various loopholes that currently exit in our extant laws and the dearth of case laws on gig employment. In the same breath, the Nigerian government is caught in a web of either allowing these companies have a field day in order to be seen as promoting economic growth and investment or the agitation by organized labour to protect the workers from exploitation. Thus they have failed to provide a statutory footing to gig workers or any other non-traditional model of employment. In addition, employers take advantage of these to continually hire workers to fill employment positions.

\subsection{LEGAL PROTECTTION AFFORDED BY THE CONTSITUTION}

One way Uber disciplines its drivers who fail to meet their standards and fall below a 4.6 ratings is by terminating the contract and abruptly removing the drivers account from the app. Section 36(1) of the 1999 constitution gives every gig worker the right to fair hearing and the benefit of being heard in determination of their civil rights by a proper body. ${ }^{4}$ Question posed however is, are these drivers given a fair trial before their removal from the platform?

Furthermore, the Constitution has empowered the National Assembly exclusively by item 34 of the Exclusive Legislative List, Second Schedule of the Constitution to legislate on labour related matters. Labour in this context; include trade unions; industrial relations; conditions; safety and welfare of workers, industrial disputes; prescribing a national minimum wage for the federation or any part thereof; and industrial powers. ${ }^{5}$ Item 17(a) part II, Concurrent Legislative List, Second Schedule of the Constitution empowers the National Assembly to enact laws for the federation or any part of it in regards to the health, safety and welfare of persons employed to work. Accordingly the National Assembly in exercise of this powers vested on them, have made laws for the purpose of protecting the interest of Nigerian workers. Such legislations include but are not limited to the Labour Act, ${ }^{6}$ National Minimum Wages Act, ${ }^{7}$ Factories Act, ${ }^{8}$ Employees Compensation Act $2010,{ }^{9}$ and Pensions Reform Act 2014. ${ }^{10}$ The next question arises thus: Does any of these legislative instruments mentioned above adequately capture the employment status of Nigerian workers in the gig economy? This question we shall attempt to answer as we explore further

\subsection{THE NIGERIAN LABOUR ACT AND ITS PROTECTION}

The Nigerian Labour Act does not expressly refer to gig workers nor does it define gig employment. As a matter of fact, there is no mention of the term 'gig' in the Act. The dearth of definition of the status of this category of workers as well as the legal framework regulating the terms and conditions of their employment and protection explains the motivating factor for the increasing use of workers by employers and why this category of workers are exploited by gig work employers who engage them. ${ }^{11}$

\footnotetext{
1 ibid (n45)

${ }^{2}$ Miriam a. Cherry, Mindestlohn fir crowdarbeit? "A minimum wage for Crowdword", in Crowdwork-Zurijck in die Zukunfr?: Perspektiven digitaler arbeit [Crowdwork-back to the future?: Perspectives on digital labor] 231- 40 '(christiane benner ed., 2014)

${ }^{3}$ Chineze Sophia Ibekwe, 'Legal Implications of Employment Casualisation in Nigeria: A Cross-National Comparison' (2016) 7 Nnamdi Azikiwe U J Int'l L \& Juris 79

${ }^{4}$ Amaka G Eze and Ted C Eze, 'A Cross National Survey of the Legal Framework for the Protection of Casual Work Arrangements in Some Selected Countries' (2013) 4 Nnamdi Azikiwe U J Int'l L \& Juris 57

${ }^{5}$ Section 4(2) 1999 Constitution

${ }^{6}$ Cap LI, LFN 2004

${ }^{7}$ Cap N61, LFN 2004

${ }^{8}$ Cap F1, LFN2004

${ }^{9}$ Assented to on 17 th December, 2010

${ }^{10}$ Act No. 4 of 2014

11 ibid (n50)
} 
Section 91(1) of the Act defined a "worker" as any person who has entered into or works under a contract with an employer, whether the contract is for manual labour or clerical work or is expressed or implied or oral or written, and whether it is a contract of service or a contract personally to execute any work or labour. ${ }^{1}$ Looking at the meaning of a worker under the Act, the said definition does not cover most workers under the category of non-traditional model of employment. The reason to this however may be ascribed to the fact that at the time the current Act was enacted, the non-traditional model work arrangement that captures the gig economy was unknown to the Nigerian employment environment

\subsection{TRADE UNION ACT}

Section 1 of the Act defines trade union as "any combination of workers or employees, whether "temporary or permanent", the purpose of which is to regulate the terms and conditions of employment of workers". Looking at the wordings in this definition, the terms whether "temporary or permanent", "workers or employees" shows the intention of the draftsman to actually capture all workers no matter their employment status. Thus granting them the right to join or form trade unions without any prior authorization from their employer in order to improve their welfare and employment conditions. This raises the very questions of; are gig workers allowed to form their own union? Why have they not been invited to any round table discussion to discuss their welfare? Rather what we have seen so far are the government and Uber blatantly holding meetings to chart ways forward without involving the drivers.

\subsection{THE POSITION IN THE EMPLOYEE COMPESATION ACT}

This Act which repealed the workmen's compensation Act $^{2}$ represents a huge step in the right direction in respect of labour rights and protection afforded to gig workers or non-traditional workers because it introduces a new security scheme for all workers in Nigeria. It made provisions for compensation to employees and their dependents for any death, injury, disease or disability arising out of or in the course of employment and other related matters. ${ }^{3}$ A notable observation of this Act is its inclusiveness in the definition of "an employee" and its applicability to all workers in Nigeria unlike the repealed Act that excluded certain categories of workers and types of employment arrangements. ${ }^{4}$

Section 73 defines an employee "as a person employed by an employer under oral or written contract of employment whether on a continuous, part-time, temporary, apprenticeship or casual basis in the federal, state and local governments and any of the government agencies and in the formal and informal sectors of the economy". This definition of an employee in this Act is the first to adequately capture both categories of workers whether traditional or non-traditional model in Nigeria. The express mention of the terms 'part-time', 'temporary' and 'casual' basis makes the application of the benefits afforded for under this Act to accrue to casual or nontraditional workers like the gig workers. ${ }^{5}$

\subsection{CONCLUSION \& SUMMARY}

It is clear right now that the binary classification of gig workers either as independent contractors or employees has not yielded any positive result so far. The continuous application of outdated legal test to determine the status of these workers presents us with even more problems.

Unfortunately, there is no direct statutory provision defining, regulating or stipulating the terms of nonstandard employment relations in Nigeria. This is a serious legislative oversight that is capable of undermining effective protection of gig economy workers. The terms and conditions usually in these types of work relations are as such subject to negotiation between the parties or are automatically offered to the worker without any negotiation. ${ }^{6}$ Accordingly workers in this form of arrangement can be dismissed at any time without notice and are not entitled to redundancy pay. Hence, it is an unprotected form of employment because it does not enjoy the statutory protection available to traditional employees under the Labour Act or any other Act in relation to employment status in Nigeria. Consequently, this article presents a new model by sketching the contours of a third type of worker: the independent employee. ${ }^{7}$ It does not attempt to provide a definitive path forward but rather to stimulate conversation for a third force category of employment status for the benefit of both companies and workers alike in view of the worker misclassification claims and counter claims that has almost derailed the gig business model. It suggest a new legal regime where the independent employee would be entitled to many of the same protections afforded to traditional employees but would be willing to substitute a

\footnotetext{
${ }^{1}$ Sec 91(1) Labour Act, Cap LI, LFN 2004

${ }^{2}$ Workmen's Compensation Act Cap W6, LFN 2004

3 ibid (n50)

${ }^{4}$ Section 1(2) Workmen's Compensation Act Cap W6, LFN 2004

5 ibid (n50)

${ }^{6}$ M.Daniel,' Protecting Workers' Rights in a Labour Environment Dominated by Nonstandard Work Arrangements and Unfair Labour

Practices: An Empirical Study of Nigeria', International Journal of Interdisciplinary Research and Innovations 2015, Vol. 3, pp 65-83

7 Michael L Nadler, 'Independent Employees: A New Category of Workers for the Gig Economy' (2018) 19 NC JL \& Tech 443
} 
degree of economic assurance for greater flexibility and control in setting the terms and conditions of their work. Additionally, the control test can be utilized in the employment law context to develop a body of case-law as to where a worker must fall on the control spectrum to qualify as an employee, independent employee, or independent contractor, without resorting to the rigid examination of every imaginable factor under the sun. Thus, when the window of opportunity presents itself, the Nigerian National assembly should rise up to the challenge and the relevant laws amended in order to adequately capture and protect employees working in the gig economy.

Consequently, let me finally describe the future of the independent employee status in the gig economy: A job that allows you render your services, explore your capacity, gives you the flexibility to do your job, make mistakes while experimenting, pays you to think, recognizes your value by rewarding you and ensure you can spend time with your loved ones while gigging. The future of work must involve designing more of this. 